\title{
Home Capital Group - The High Cost of Dishonesty
}

\author{
Kareen Brown \\ Goodman School of Business \\ Brock University \\ kbrown6@brocku.ca \\ Kevin Veenstra* \\ DeGroote School of Business \\ McMaster University \\ veenstk@mcmaster.ca
}

January 11, 2018

\section{Acknowledgments:}

We are thankful for constructive comments and suggestions from two reviewers. Veenstra gratefully acknowledges the financial support of McMaster University. All errors are our own.

* Corresponding Author: Kevin Veenstra, Assistant Professor of Accounting, DeGroote School of Business, McMaster University, 1280 Main Street West, Hamilton, ON L8S 4M4, Canada. Email: veenstk@mcmaster.ca Tel: 1-905-525-9140 ext. 23991; Fax: 1-905-526 0852. Suggested answers to case questions are available from corresponding author upon request. 


\title{
Home Capital Group - The High Cost of Dishonesty
}

\begin{abstract}
This instructional case presents the problems that began in the summer of 2015 when Home Capital Group (HCG) announced it had cut ties with 45 mortgage brokers for falsifying figures on mortgage applications regarding the earnings of prospective home purchasers in Canada. The case details the subsequent investigation by the Ontario Securities Commission in 2017 that resulted in a run on the bank and consequent efforts by HCG to stay afloat. While emphasizing the importance of strong corporate governance and Corporate Social Responsibility (CSR) initiatives, this case also stresses the influence of various stakeholders including short-sellers, regulators, shareholders, management, depositors, and customers in the evolution of subsequent events. As a whole, this case provides an interesting context for the discussion of stock market efficiency.
\end{abstract}

Keywords: corporate governance; corporate social responsibility; accounting theory; banking

"Home Capital suffered a crisis of poor governance. With the recent changes in the composition of its board of directors they have an opportunity to turn things around." Dustyn Lanz, Chief Operating Officer, Responsible Investment Association, August 9, 2017.

"We know that we have not met the full expectations of some of our valued stakeholders, which we deeply regret. These changes will ultimately result in enhanced management and governance leadership, and bring valuable new perspectives to Home Capital.” Kevin Smith, Chair of Home Capital's board, April 24, 2017. 


\section{Home Capital Group}

Cam sighs at the clutter of papers littering the table of the Starbucks coffee shop in the Student Centre. "This is an impossible assignment," he complains to his three team members from a final year Corporate Governance class. "Even the experts can't agree on whether investors should buy or sell this stock. Short sellers like Marc Cohodes ${ }^{i}$ have been betting against the stock because of Home Capital's lending practices and concerns about the stability of the housing market here in Canada. Baskin Wealth Management Group (Baskin), which owned the stock from as far back as 2003, just liquidated its position because it lost confidence in the company's management."

"Yeah, but in that video" we watched Barry Schwartz" from Baskin say they anticipated a run on the bank. That didn't happen,” Ben interjects.

“And don't forget Warren Buffet. He won't back a losing stock,” David adds.

"Fair enough," Cam shoots back. "But Baskin's concerns in this letter to its clients are still valid.” He reads from a highlighted portion of a crumpled paper, “...These [concerns] include class-action lawsuits which have already been launched, the replacement of key senior managers, and, most importantly, the re-establishment of a solid level of trust with both institutional and retail investors. There is much hard work to be done, and we cannot know how it will all turn out," he finishes. ${ }^{\text {iv }}$

Jenny, the only woman in the group, finally joins the conversation. "Maybe it would help if we discuss what we know so far. I've read up on how HCG got started, its key executives, and corporate governance practices. This is what I found out..." She reads aloud from her laptop.

Home Capital Group Inc. is a public company listed on the Toronto Stock Exchange under the ticker symbol, HCG, with headquarters in Toronto, Canada. Considered an alternative mortgage lender, it now serves approximately $20 \%$ of Canadians who are unable to qualify for residential mortgages with a traditional bank. During the 1980s, the mortgage industry consisted of several large mortgage lenders whose business models were unable to cope with unconventional borrowers. However, HCG carved out a niche sector of the market to provide loans and insurance to higher risk or low credit score clients. Currently, the majority of its clients are recent immigrants and/or self-employed individuals deemed too risky by the larger lenders because they lack steady income or sufficient credit history in Canada.

HCG was founded by Mr. Gerald (Jerry) M. Soloway with the purchase of an inactive energy company (Sonor Resources Corporation). Prior to HCG, Soloway practiced real estate, mortgage, and commercial law on behalf of banks and trust companies. Soloway's company went public in October 1986, when it divested its energy operations and founded Kingsway General Insurance Company. In December 1986, Kingsway acquired Home Savings and Loan Corporation and changed the parent company's name to Home Capital Group Inc. For the fiscal year ending December 31, 1986, HCG had total assets of \$70 million and serviced mortgage loans of \$49 million. In the subsequent years Soloway pursued an aggressive growth strategy, fueled by successful acquisitions and a focus on excellent customer service at the local level in 
the metropolitan Toronto, Hamilton, and St. Catharines markets. In 1989, HCG divested its interest in Kingsway and focused its efforts for the next eleven years on the financial services market. In March 2000, Home Savings and Loan was converted to a federally regulated trust company, under the name of Home Trust Company, offering financial products such as deposits, mortgages, and retail credit services. Home Trust Company, a 100\% owned subsidiary of HCG, is authorized to conduct business across Canada. Currently, it has offices located in the provinces of Ontario, Alberta, British Columbia, Québec, Nova Scotia, and Manitoba. ${ }^{\vee}$ On December 31, 2014, HCG reported total revenues of just over $\$ 1$ billion, total assets of $\$ 20$ billion, and mortgage loans of \$18 billion. Exhibit 1 presents key financial performance indicators for HCG.

HCG's residential mortgage business consists largely of two portfolios: (1) Accelerator mortgages, which are its main insured single-family product available to prime borrowers (the majority of whom are insured by the Canada Mortgage and Housing Corporation (CMHC)); and (2) conventional mortgages, which are not insured. Residential mortgages comprise approximately 90\% of HCG's business. On December 31, 2016, Home Trust was the fifth largest supplier of mortgages in Canada, commanding 7.7\% of the market. At the end of Q1 2017, Home Trust ranked third with a market share of $10.7 \%$.

\section{Corporate Governance}

Jerry Soloway served as the company’s CEO from January 1, 1987 to May 11, 2016; as President until January 2008; and as an executive director until May 2017. He was also the CEO and President of Home Trust Company from 1986 until May 11, 2016. Martin K. Reid joined HCG in September 2007 as Treasurer with more than 30 years of experience in the financial services industry. He became President of HCG, Home Trust Company, and CFF Bank (a subsidiary of Home Trust Company) on January 1, 2010. He was appointed President and Chief Executive Officer of all three entities on May 11, 2016. Robert L. Morton, a Chartered Professional Accountant, served as Executive Vice President and Chief Financial Officer of HCG and Home Trust Company from January 1, 2015 until June 27, 2017. ${ }^{\text {vi,vii }}$ (See Exhibit 2 for key personnel and the years they held office).

Beginning in 1989, HCG's Board of Directors established an audit committee comprised of independent directors. Also in 1989, HCG established a system of internal controls to provide reasonable assurance of the reliability of financial information and to protect the assets under its control. The 2004 annual report states,

The Company maintains a governance and control framework to ensure that its operations are efficient and effective, that the financial reporting is reliable, and that the Company complies with all applicable laws and regulations. To this end, written policies and procedures relating to the Company's business activities are in place and are reviewed no less than annually by the Board of Directors. In addition, external auditors and government regulators review the internal controls. The Company has an internal auditor accountable directly to the Chairman of the Audit and Risk Management Committee who examines and reports on the effectiveness of internal controls and related matters. The internal auditor's role complements the external audit functions and, to this end, the internal auditor communicates throughout the year with both the external 
auditors and government regulators. The Company has established a compliance function responsible for business and employee conduct and legislative compliance that reports to the Company's Conduct Review Committee.

Effective March 17, 2014, HCG adopted corporate governance guidelines to reflect regulatory changes and to remain consistent with the rules adopted by the Canadian Securities Administrators (CSA) and industry best practices. For the fiscal year ending December 31, 2014, HCG determined that all directors were independent with respect to the CSA rules, with the exclusion of Mr. Gerald M. Soloway, Chief Executive Officer at the time. Consistent with generally accepted corporate governance practices, the roles of the Chair of the Board and Chief Executive Officer were separate. Kevin Smith, who was the Chair of the Board and the Human Resources and Compensation committee, was deemed independent, having never held an executive position in HCG. In addition, the board consisted of eight other members: (1) The Honourable William G. Davis, P.C., C.C., Q.C. - Vice Chair of the board; (2) James C. Baillie; (3) Jacqueline Beaurivage, Vice President of ePMO \& Strategy at Ontario Teachers' Pension Plan (OTTP); (4) William Falk, Managing Partner of PricewaterhouseCoopers; (5) Diana Graham; (6) John M.E. Marsh; (7) Bonita J. Then; and (8) Robert A. Mitchell, CPA.

By 2014 HCG had adopted written descriptions for the positions of Chair of the Board, Vice Chair of the Board, Committee Chairs, Vice Chair of Committees, individual directors, and the Chief Executive Officer. Currently, the company has independent committees in the following areas: (1) audit; (2) governance, nominating, and conduct review; (3) human resources and compensation; and (4) risk and capital. On March 11, 2015, the company established formal job descriptions for each director position, a shareholder rights plan, and a Code of Business Conduct and Ethics for all directors, officers, and employees. ${ }^{\text {viii }}$ The Code of Business Conduct and Ethics outlines business conduct and provides guidelines for employees regarding questionable audit or accounting matters.

In addition to the policies noted above, the corporation has a disclosure policy regarding communications to all stakeholders that emphasizes the dissemination of "timely, factual, complete and accurate" information and the issuance of financial statements that are stated fairly in accordance with Generally Accepted Accounting Principles (GAAP). Finally, the company has an official whistleblower policy.

HCG engages in several CSR activities in its local communities. For example, its 2015 annual report documents employee volunteerism in the Junior Achievement of Canada programs for Grade 7 and Grade 8 students in Toronto, a Habitat for Humanity construction project, and initiatives to deliver food to homeless youth and local women's shelters. The annual report states the firm's commitment to encouraging employees to make green choices, and it supports the environment by donating trees to Tree Canada's National Greening Program. In 2015, HCG launched the Reigniting Our Culture event to promote employee involvement in shaping the company's values (see Exhibit 3). 


\section{Regulations in the Canadian Housing Market}

Taking a careful sip of his steaming vanilla latte, Ben says, "One important aspect of this case is what it says about the adequacy of the regulations for the housing market here in Canada. I think everyone is aware of the 2007 U.S. housing crisis, and no one wants that to happen here. I've done some research on the regulations for the Canadian Housing Market." He hands out a report.

The Canadian housing market has several unique features that should reduce loan defaults. First, only two provinces, Saskatchewan and Alberta, have non-recourse mortgages preventing lenders from garnishing a borrowers' wages or seizing assets besides the one purchased with the mortgage. Second, the Canadian mortgage industry is regulated by federal and provincial legislation limiting insured mortgage amortization terms. In 2010 and 2011, then Minister of Finance, Jim Flaherty, announced three amendments to the rules for government-backed insured mortgages to "support the long-term stability of Canada's housing market and continue to encourage home ownership for Canadians." "ix These initiatives included: (1) a requirement for borrowers to meet qualifications for a five-year fixed rate mortgage using a bank's posted rates, regardless of whether lower interest rates and/or shorter terms are negotiated; (2) a reduction in the maximum amount that borrowers are able to withdraw during refinancing from 95\% to 90\% of their home value; and (3) a minimum 20\% down payment for non-owner-occupied properties purchased for speculation and/or investment. ${ }^{\mathrm{x}}$ Most recently, effective February 15, 2016, a minimum $10 \%$ down payment is required on the portion of the purchase price over $\$ 500,000$ (5\% for the first $\$ 500,000$ ). In addition, borrowers making lower down payments are required to hold additional insurance. ${ }^{\mathrm{xi}}$

Commercial and residential mortgages in Canada are provided by three main lender groups. The majority of loans to customers with favorable credit histories are serviced by institutions known as "A" lenders. These institutions include such banks as Scotiabank, TD Canada Trust, and CIBC. These lenders use borrowers' income and credit ratings to determine mortgage rates. Alternative mortgage lenders such as HCG; also called subprime or "B" lenders, service customers without established credit histories. They charge higher mortgage rates than " $A$ " lenders because their customers are riskier.

Private mortgage lenders, such as Alta West Mortgage and Capital Direct Lending, provide uninsured loans to higher risk borrowers. To reduce their risk, these lenders perform a strict appraisal of the property to be mortgaged. In Canada, the market share for private lenders almost doubled between 2007 and 2016, largely due to increasingly tougher lending rules imposed on regulated mortgages.

Among the top 10 mortgage broker lenders are Scotiabank and TD Canada Trust, two of the Big 6 Canadian banks. Scotiabank commands the largest market share with $18.5 \%$ in the fourth quarter of 2016 and 23\% in the first quarter of 2017. Scotiabank has invested heavily in fin-tech and now offers customized mortgage choices in its effort to compete for price-sensitive, online customers. TD Canada Trust holds a steady 7.0\% - 7.5\% of the broker market share. Broker channel origination volume is approximately one third of all mortgage origination volume in Canada. 
HCG's fiercest competitor is Equitable Bank, a wholly-owned subsidiary of Equitable Group that provides mortgages for owner-occupied and investment properties across Canada. Street Capital Financial, another HCG competitor and large non-bank lender, provides residential mortgages through select independent mortgage brokers.

\section{Management Makes “Materially Misleading Statements” xii, xiii}

"Sounds like there were strong regulations and HCG had a pretty successful business model. I mean, the financial statements show steady growth since 1986," David reasons.

"A lot went wrong, though. That is where my research comes in," Cam interjects. "I got most of my information from the April 19, 2017 Statement of Allegations of Staff of the Ontario Securities Commission." He reads aloud.

The OSC cites June 2014 as the month that HCG first learned of possible data irregularities in several mortgage applications submitted by mortgage brokers to HCG for approval. During August 2014, a special committee of HCG's board of directors launched an internal investigation, called Project Trillium, which concluded in February 2015 that several brokers had supplied fraudulent income information that went undetected by HCG's underwriting controls. By February 10, 2015, in response to the findings of Project Trillium, HCG terminated the employment of four underwriters, two brokerages, and 30 brokers, and placed several other brokers on a watch list. HCG took steps to rectify the internal controls over the underwriting processes, such as separating sales from underwriting and confirming employment and income information. These changes caused an immediate drop in mortgage originations for two reasons. First, the terminated brokers had generated \$881.4 million in mortgage originations in 2014, approximately $10 \%$ of HCG's total 2014 originations; and second, the additional controls increased processing times for mortgages, thereby causing brokers to send mortgage applications to other lenders. HCG also deliberately reduced growth to facilitate the planned remediation of controls for its residential mortgages, and deferred compensation for Gerald Soloway, CEO and Martin Reid, President (see Exhibit 4).

The OSC claims that although Soloway (CEO) and Morton (CFO) were aware of the underlying reasons for the drop in mortgage originations, they had withheld from investors material information about the reasons for the decline in mortgage originations, broker terminations, and the corrective actions being undertaken. On February 11, 2015, Home Capital Group filed its annual financial statements for 2014. The MD\&A attributes the decline in mortgage originations to "external vagaries such as macroeconomics, seasonality, and competitive markets", rather than to the termination of several brokers in response to the detection of fraud. The only reference made to the difficulties in mortgage originations is the following excerpt in the Operational Risk section of the MD\&A:

In addition to cyber-crime, the Company is continuously exposed to other various types of fraud stemming from the nature of the Company's business. For example, the Company must often rely on information provided by customers and other third parties in 
its decisions to enter into transactions such as extending credit. The recent increasing pace of advancement in available technology has increased the sophistication and complexity of potential fraud crimes to which the Company is exposed.

The CEO and CFO both certified the 2014 Annual Filing. No mention was made of the fraudulent information by brokers in the subsequent 2015 first quarter filings on May 6, 2015. The OSC claims that the executives' failure to disclose material information was a breach of subsection 122(1)(b) of the Securities Act, R.S.O. 1990, c.S.5, as amended, and National Instrument 52-109 - Certification of Disclosure in Issuers' Annual and Interim Filings (NI 52109).

Jerry Soloway made materially misleading statements to analysts about the causes of the drop in mortgage originations during a May 7, 2015 conference call. In response to a direct question from an analyst about the reasons for the decline in Originations for Q1 2015, Soloway ascribed the continuing drop in originations to cold weather, macroeconomic conditions, and a conservative lending approach.

On June 1, 2015, the chair of HCG's audit committee received a "Whistleblower Memorandum" from a vice-president of HCG regarding the company's failure to disclose the findings of fraudulent information from certain brokers. The memorandum referenced the Whistleblower Policy and the Code of Conduct \& Ethics Policy of HCG. A few days later HCG voluntarily delivered to OSC staff the "whistleblower memorandum." The OSC began investigations.

HCG publicly announced for the first time on July 10, 2015 that they had terminated relationships with several brokers based on an internal assessment of its business partners. This announcement caused an immediate drop in mortgage originations and on July 13, 2015 HCG shares fell 18.9\% (see Exhibit 5). On July 30, 2015, in another conference call with analysts, CEO Gerald Soloway informed investors that audits were conducted on the affected mortgages. He assured investors that the insurers had expressed no concerns about covering any claim that might result from these mortgages. He stressed that the affected mortgages were performing as well as other residential mortgages because the loans were being paid by multiple income earners residing in the home.

Beginning in February 2016, HCG announced a series of personnel changes to its executive team. On February 29, 2016, HCG announced the planned retirement of CEO and co-founder, Gerald Soloway. Martin Reid was named as successor and appointed CEO on May 11, 2016.

The company disclosed on March 14, 2017 that the OSC had issued enforcement notices to current and former executives for non-disclosure of fraudulent activities by certain mortgage brokers who had submitted mortgage applications with falsified information. On March 27, 2017, HCG announced the immediate termination of Martin Reid, CEO, stating the need for "leadership that can bring to bear a renewed operational discipline, emphasis on risk management and controls, and focus on improving performance.” Bonita J. Then, a member of the Home Capital Group Board of Directors since 2008, was appointed as interim President and CEO. ${ }^{\text {xiv }}$ 
On April 19, 2017, the OSC named Gerald Soloway, Robert Morton, and Martin Reid in a notice of hearing and statement of allegations. The OSC alleged that Soloway and Morton had certified financial statements that omitted material information regarding falsified loan applications. Additionally, the OSC alleged that Soloway and Reid had made misleading or false statements on the May 7, 2015 conference call.

HCG announced on April 26, 2017 that it had received a \$2 billion line of credit lifeline from the Healthcare of Ontario Pension Plan (HOOPP) to compensate for withdrawals from its Home Trust High Interest Savings Accounts. The line of credit was subject to an immediate draw of $\$ 1$ billion, and required HCG to pay an upfront commitment fee of \$100 million to HOOPP. The interest rate on the outstanding amount borrowed is $10 \%$, and the "standby fee" for undrawn funds is $2.5 \%$. The line of credit translates to an effective interest rate of $22.5 \%$ on the first $\mathrm{C} \$ 1$ billion drawn down. On the announcement that HCG had obtained this line of credit, Home Capital Group’s (HCG) stock price fell from \$17 per share to a closing price of \$5.99 per share (see Exhibit 5).

At its highest point in August of 2014, the stock was trading at $\$ 55.24$ a share. Even during the financial crisis of 2008/2009, the company's stock price had reached a low of only $\$ 7.50$. The April 26, 2017 decline in stock price was largely in response to the April 19, 2017 accusations by the Ontario Securities Commission (OSC) that Home Capital had made "materially misleading statements" to its shareholders during the period of February 2015 to May 2015. HCG positions itself as a growth company, and analysts and investors consider the number of mortgage originations as a key metric of HCG's growth. In the aftermath of the OSC accusations, HCG lost approximately 95\% of customer deposits in high interest savings, from $\$ 2$ billion to approximately $\$ 100$ million as of June 25, 2017. Average daily gross guaranteed investment certificate (GIC) deposits fell to a low of C\$4 million on May 12, 2017, directly affecting HCG's ability to originate new mortgage assets.

Subsequent to the "collapse” of HCG's share price on April 26, 2017, shares in Equitable Bank, HCG's closest competitor, fell more than $25 \%$ due in large part to the fear of contagion from the HCG crisis. In response, on May 3, 2017, Equitable Bank announced that had it obtained a letter of commitment for a two-year, $\$ 2.0$ billion secured backstop funding facility from a syndicate of the Big 6 Canadian banks, including the Bank of Montreal, CIBC, National Bank, Royal Bank of Canada, Scotiabank, and Toronto-Dominion Bank. The terms of this offer, while more attractive than those obtained by HCG, included a $0.75 \%$ commitment fee, a $0.50 \%$ standby charge on any unused portion of the facility, and an interest rate on the drawn portion of the facility equal to the Banks' cost of funds plus 1.25\%. While Equitable's CEO attributed the acquisition of the facility to prudent risk-reduction practices, industry insiders speculate that OSFI may have had some influence in its swift arrangement. (OSFI is an independent government agency, reporting to the Minister of Finance. As the sole regulator of banks, and the primary regulator of insurance companies, trust companies, loan companies, and pension plans in Canada, OSFI's main objective is to instill public confidence in the Canadian financial system.) 


\section{Warren Buffet Invests in HCG}

"I think that the media frenzy about the misleading statements made by HCG executives is a storm in a teacup," argues David. "Sure, HCG had some problems, but it was their own corporate governance standards that got the problem reported to the OSC in the first place. There are several positive indicators that HCG is a solid investment opportunity." As he starts to tick off points on his finger, David makes his point: "First..."

1. The company has made several changes to strengthen its Corporate Governance and rebuild investor confidence. They have added executives and directors with a breadth of experience in risk management and accounting. Yousry Bissada was appointed Chief Executive Officer on August 3, 2017. A Chartered Professional Accountant, he has decades of experience as an executive and director in the financial services and mortgage industry. Brenda Eprile was appointed Chair of the Board of directors on May 8, 2017. Ms. Eprile, who was Executive Director and Chief Accountant at the OSC, has an extensive business background specializing in risk consulting. Three new board members were also announced - Claude Lamoureux, Paul Haggis, and Sharon Sallows. Claude Lamoureux is the former Chief Executive Officer of the Ontario Teachers' Pension Plan and a co-founder of the Canadian Coalition for Good Governance. Paul Haggis is former CEO of Ontario Municipal Employees Retirement System (OMERS) and former CEO of Alberta Treasury Branches. Sharon Sallows brings experience from the real estate industry in lending and investment.

2. On May 11, 2017 HCG arranged with an independent third party to accept mortgage commitments and/or renewals of up to a total of $\$ 1.5$ billion with the potential for expansion. The company also suspended paying dividends to shareholders to shore up liquidity. ${ }^{\mathrm{xv}}$

3. On June 14, 2017, HCG announced that, subject to court approval, it had reached settlement agreements with the Ontario Securities Commission regarding the putative class action lawsuit related to claims of misleading disclosure. HCG is expected to make a payment of $\$ 29.5$ million (net of costs and other expenses). This includes a settlement to the OSC in the amount of \$10 million for the benefit of Home Capital investors. HCG will also reimburse the OSC's costs of $\$ 500,000$. The costs of such settlements are expected to be funded entirely through available liability insurance. In addition, Gerald Soloway is prohibited from acting as a director or officer of any public company for four years, and he has incurred an administrative penalty of \$1 million. Robert Morton and Martin Reid, who are barred from roles as directors or officers of reporting issuers for a two-year period, must each pay an administrative penalty of $\$ 500,000 .^{x v i}$

4. On June 22, 2017, Berkshire Hathaway, through its subsidiary Columbia Insurance Co., agreed to provide a new C $\$ 2$ billion loan facility to HCG with an interest rate of $9 \%$ and a standby fee on funds not drawn in the amount of $1.75 \%$. Berkshire Hathaway also agreed to purchase \$153.2 million of HCG stock, representing a 19.99\% ownership interest in the company at a price of $\$ 9.55$ per share, with a closing date of June 29, 2017. In addition, Berkshire committed to making a second investment in the corporation of \$246.8 million to acquire an additional 23,955,420 common shares at a price of approximately $\$ 10.30$ per share, subject to shareholder approval in September 2017. If the Berkshire second tranche is 
completed, Berkshire will indirectly hold an approximate 38.39\% equity interest in HCG. Following the announcement, HCG's stock price increased by $11.4 \%$, closing at $\$ 16.65$, with a high of $\$ 18.94$.

On June 29, 2017, HCG announced the Toronto Stock Exchange approval of the first tranche of Berkshire Hathaway Inc.'s 19.99\% investment in Home Capital at C $\$ 9.55$ a share. This first sale is allowed without shareholder vote under the "financial hardship" exemption from the Toronto Stock Exchange. The Chair of the Board, Brenda Eprile, argued in support of the sale of the shares at a deep discount, stating: "We think the Buffett brand brings instant credibility to our deposits and will enable us to continue to rely on this as a stable source of funding.” This view was endorsed by several investors at the annual meeting. ${ }^{\text {xvii }}$

5. Warren Buffet thinks HCG is a great investment. "Home Capital's strong assets, its ability to originate and underwrite well-performing mortgages, and its leading position in a growing market sector make this a very attractive investment," said Warren Buffett, Berkshire chairman and CEO.

6. On July 26, 2017 HCG announced a significant improvement in its financial condition and stated that it had repaid the outstanding balance of $\$ 1.6$ billion on a $\$ 2.0$ billion credit line supplied by Berkshire.

"The company could not have been in such bad shape if they were able to repay the balance so quickly. I still do not see what the big deal is with HCG," David finishes. "The mortgages issued from falsified income were only $10 \%$ of total mortgage originations. Further, the audit showed that they were low risk, they were being paid, and they were not close to default."

"But the issue is bigger than just HCG," Jenny says quietly. "Considerable debate surrounds the implications of Home Capital's problems for the Canadian economy. On the one hand, the Canadian Bankers Association reported a 90+ day delinquency rate for conventional residential mortgages in Canada of only $0.28 \%$, significantly lower than the $11 \%$ delinquency rate in the US market prior to the 2007/2008 financial crisis. This is thought to be due to a combination of factors, including record high house prices in the greater Toronto and Vancouver areas, a 6.3\% unemployment rate as of July 2017 (the lowest in Canada since October of 2008), and legal restrictions preventing Canadians from abandoning assets with negative equity value.

"On the other hand, reports of misleading information by Home Capital have led some stakeholders to question the transparency of Canadian financial institutions, fearing Home Capital's current issues are analogous to a 'canary in the coal mine' and that a potential housing price correction in Canada will be sufficient stimulus to bring problems to light. While the Canadian Mortgage and Housing Corporation (CMHC) has stringent regulations governing mortgage insurance eligibility because it insures these lenders, it also relies on these same lenders to comply with the rules. This relationship results in a moral hazard issue for lenders, providing an incentive to relax lending standards to gain more business as the risk of potential default lies with the CMHC. However, CMHC and other private insurers do have the ability to deny lender claims to recoup losses if the lender committed fraud and/or provided 
inaccurate/misleading information when submitting the mortgage insurance application," Jenny explains.

"True," Cam agrees. "I just read a Financial Post article ${ }^{\text {xviii }}$ that said the same brokers who caused the problems at HCG can still win business because they have not been prosecuted. What if it happens on a bigger scale to other mortgage lenders? Isn't this case showing that our regulations are not as strong as they should be?" 


\section{Exhibit 1 - Key Financial Performance Indicators}

\begin{tabular}{|c|c|c|c|c|c|c|}
\hline (000s) & 31-Dec-10 & 31-Dec-05 & 31-Dec-00 & 31-Dec-95 & 31-Dec-90 & 31-Dec-86 \\
\hline Total assets & $\$ 7,712,239$ & $3,284,829$ & 881,925 & 340,826 & 430,299 & 70,366 \\
\hline Deposits \& Borrowings & $\$ 6,522,850$ & $2,901,515$ & 813,182 & 314,631 & 398,213 & 54,161 \\
\hline Mortgage loans & $\$ 5,832,569$ & $2,796,873$ & 773,065 & 305,938 & 349,933 & 49,434 \\
\hline Total shareholders' equity & $\$ 742,280$ & 218,885 & 49,501 & 19,406 & 23,300 & 12,629 \\
\hline $\begin{array}{l}\text { Total Revenues (For Fiscal } \\
\text { Year) }\end{array}$ & $\$ 533,937$ & 234,704 & 70,606 & 34,790 & 57,731 & 186 \\
\hline
\end{tabular}

\begin{tabular}{|c|c|c|c|c|c|c|}
\hline (000s, except \%, multiples and per share amounts) & $\begin{array}{r}\text { For the three } \\
\text { months ended } \\
\text { June } 30,2017\end{array}$ & \begin{tabular}{|r|} 
For the year \\
ended \\
December 31, \\
2016
\end{tabular} & \begin{tabular}{|r|} 
For the year \\
ended \\
December 31, \\
2015
\end{tabular} & $\begin{array}{r}\text { For the year } \\
\text { ended } \\
\text { December } \\
31,2014\end{array}$ & $\begin{array}{r}\text { For the year } \\
\text { ended } \\
\text { December } \\
31,2013\end{array}$ & $\begin{array}{r}\text { For the year } \\
\text { ended } \\
\text { December } \\
31,2012\end{array}$ \\
\hline \multicolumn{7}{|l|}{ FINANCIAL PERFORMANCE MEASURES } \\
\hline Total revenue & $\$(61,293)$ & $\$ 967,719$ & $\$ 995,767$ & $\$ 1,042,986$ & $\$ 949,547$ & $\$ 887,685$ \\
\hline Net income & $(111,116)$ & 247,396 & 287,285 & 313,172 & 256,542 & 221,983 \\
\hline Net interest income & $(3,407)$ & 485,164 & 481,090 & 459,529 & 421,979 & 381,472 \\
\hline Earnings per share - diluted & -1.73 & 3.71 & 4.09 & 4.45 & 3.66 & 3.19 \\
\hline \multirow[t]{2}{*}{ Return on shareholders' equity } & $-26.1 \%$ & $15.3 \%$ & $18.7 \%$ & $23.8 \%$ & $23.9 \%$ & $25.5 \%$ \\
\hline & June 30, 2017 & $\begin{array}{r}\text { December 31, } \\
2016\end{array}$ & $\begin{array}{r}\text { December 31, } \\
2015 \\
\end{array}$ & $\begin{array}{r}\text { December } \\
31,2014 \\
\end{array}$ & $\begin{array}{r}\text { December } \\
31,2013 \\
\end{array}$ & $\begin{array}{r}\text { December } \\
31,2012 \\
\end{array}$ \\
\hline \multicolumn{7}{|l|}{ FINANCIAL CONDITION MEASURES } \\
\hline Total assets & $\$ 20,077,150$ & $\$ 20,528,777$ & $\$ 20,527,062$ & $\$ 20,082,744$ & $\$ 20,075,850$ & $\$ 18,800,079$ \\
\hline Deposits \& Borrowings & $13,104,606$ & $15,886,030$ & $15,665,958$ & $13,939,971$ & $12,765,954$ & $10,136,599$ \\
\hline
\end{tabular}

Source - HCG annual and quarterly reports 
Exhibit 2 - HCG Executive Officers

\begin{tabular}{|c|c|c|c|}
\hline Name & Position & Date Started & Date ended \\
\hline \multirow{3}{*}{$\begin{array}{l}\text { Mr. Gerald } \\
\text { (Jerry) M. } \\
\text { Soloway }\end{array}$} & CEO HCG & January 1, 1987 & May 11, 2016 \\
\hline & President HCG & January 1, 1987 & January 2008 \\
\hline & $\begin{array}{l}\text { CEO and President of Home Trust } \\
\text { Company }\end{array}$ & 1986 & May 11, 2016 \\
\hline \multirow{3}{*}{$\begin{array}{l}\text { Mr. Martin K. } \\
\text { Reid }\end{array}$} & Treasurer HCG & September 2007 & December 31, 2009 \\
\hline & $\begin{array}{l}\text { President of HCG, Home Trust } \\
\text { Company and CFF Bank (a subsidiary } \\
\text { of Home Trust Company) }\end{array}$ & January 1, 2010 & March 27, 2017 \\
\hline & $\begin{array}{l}\text { Chief Executive Officer of HCG, } \\
\text { Home Trust Company and CFF Bank } \\
\text { (a subsidiary of Home Trust } \\
\text { Company) }\end{array}$ & May 11, 2016 & March 27, 2017 \\
\hline Robert L. Morton & $\begin{array}{l}\text { Executive Vice President and Chief } \\
\text { Financial Officer of HCG and Home } \\
\text { Trust Company }\end{array}$ & January 1, 2015 & June 27, 2017 \\
\hline Bonita J. Then & Interim President and CEO of HCG & March 27, 2017 & August 3, 2017 \\
\hline \multirow[t]{2}{*}{ Robert Blowes } & $\begin{array}{l}\text { Executive Vice President and Chief } \\
\text { Financial Officer of HCG and Home } \\
\text { Trust Company }\end{array}$ & 2011 & December 31, 2014 \\
\hline & Interim CFO of HCG & June 27, 2017 & August 31, 2017 \\
\hline Yousry Bissada & $\begin{array}{l}\text { President, CEO \& Director } \\
\text { Home Capital Group Inc., Home } \\
\text { Trust Company, and Home Bank }\end{array}$ & August 3, 2017 & Present \\
\hline
\end{tabular}




\section{Exhibit 3 - Excerpt from HCG 2015 Annual Report}

\section{Corporate Social Responsibility}

\section{A Commitment to Our Communities}

Home Capital invests in our neighbourhoods and communities through a wide range of corporate initiatives, sponsorships and employee fundraising efforts. We are proud to partner with organizations whose focus aligns with our principles - financial literacy, an entrepreneurial culture, serving the underserved, and our belief in every Canadian's right to shelter. In 2015, employee volunteers participated in a number of events including Junior Achievement of Canada programs for Grade 7 and 8 students in Toronto, a Habitat for Humanity construction project, delivering a day of assistance and support to homeless youth at Covenant House and a soupmaking session with Soup Sisters Toronto to provide soup to local women’s shelters and youth programs. Employees also supported Camp Oochigeas for children with cancer by participating in a fundraising barbeque and taking part in readying camp facilities in Muskoka.

\section{A Commitment to Our Employees}

We invest in our employees by creating a workplace where people feel engaged, inspired, challenged, proud and respected. To that end, we focus on all facets of the employee experience and work to foster employee engagement through the promotion of a climate of trust and encouragement. We support our employees and their commitment to their communities through sponsorships of local sports teams, neighbourhood events and little league squads. We are proud of our more than 300 employees who volunteered for numerous events organized over the year by the Company's Corporate Social Responsibility Committee, demonstrating a high level of interest and enthusiasm. In 2015, Home Capital launched its new vision, mission and values with a company-wide event, Reigniting Our Culture. This event promoted deeper employee engagement and involvement in helping to shape what our values look like in action and create an environment where employees can grow and prosper.

\section{A Commitment to Our Environment}

Home Capital is committed to implementing environmentally sustainable business practices that reduce our impact to the environment. We achieve this through employee awareness programs, encouraging employees to make green choices, and supporting business practices and participating in initiatives that benefit the environment in practical and meaningful ways. In 2015, a number of employees took part in an initiative with Nature Conservancy Canada, a non-profit organization that focuses on conservation and protection of natural areas that sustain Canada's plants and wildlife. Through this program, volunteers helped clear invasive species in the Niagara Escarpment, supporting the preservation of this area of natural diversity in southern Ontario. In further efforts to support the environment, the Company donated one tree for each employee to Tree Canada's National Greening Program, helping reforest areas of British Columbia hit hardest by devastating wildfires in 2015. 
Exhibit 4 - Home Capital Group - Mortgage Originations

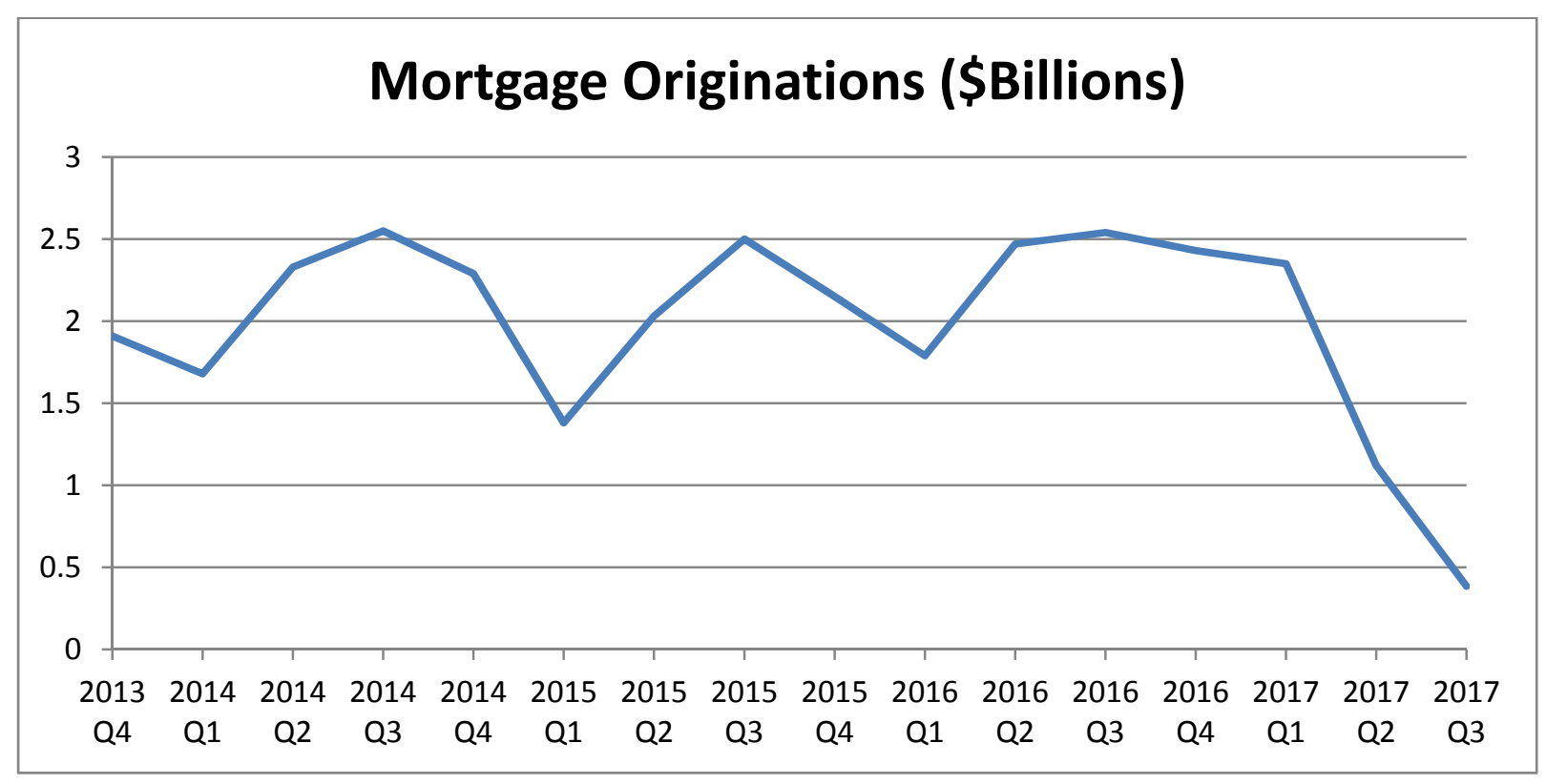

Source: Home Capital Group annual and quarterly reports 


\section{Exhibit 5 - Home Capital Group - Daily Closing Prices January 2015 - August 2017}

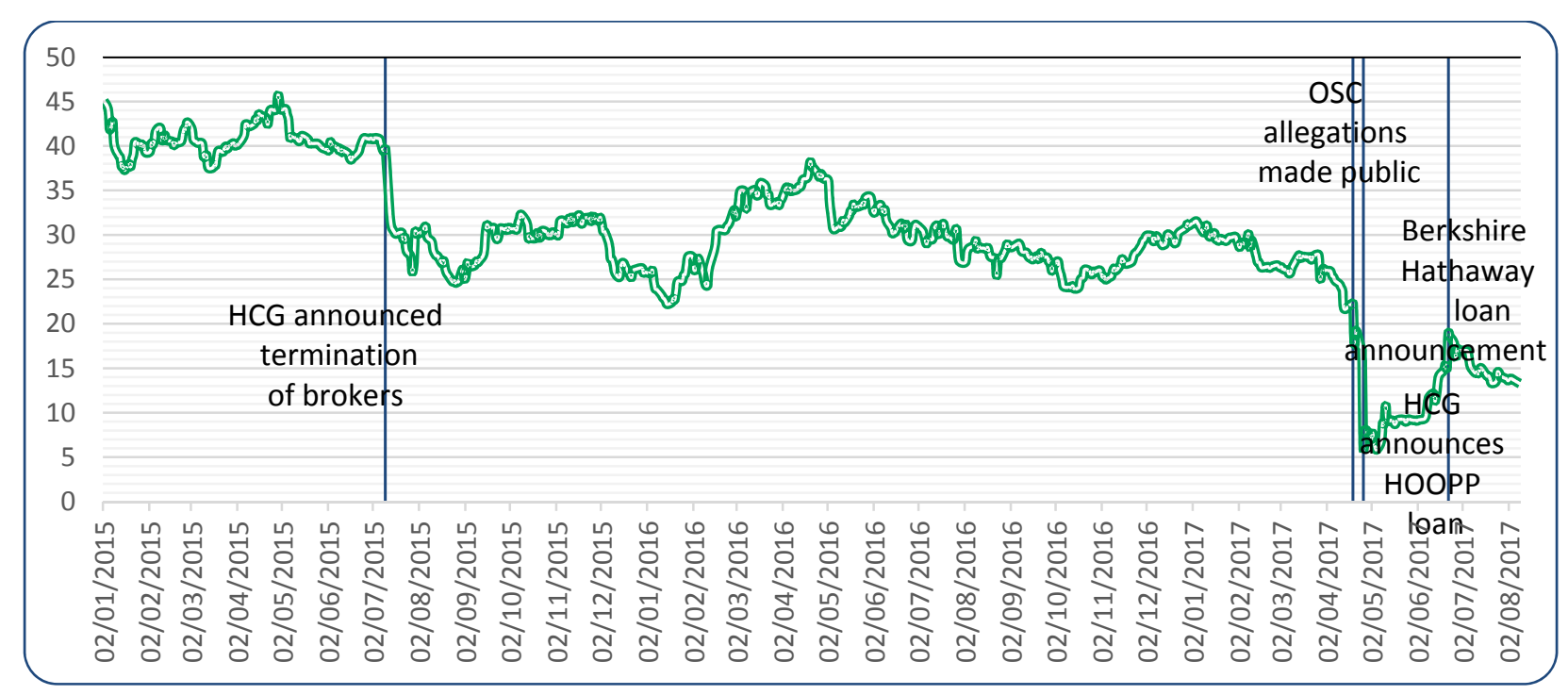

Source: Center for Research in Security Prices 


\section{Teaching Notes:}

\section{Learning Objectives}

The Home Capital Case provides a contextually rich setting in which to discuss the causes and consequences of corporate governance lapses, the elements of corporate social responsibility (CSR), unintended consequences of information asymmetry (adverse selection), and finance topics such as short-selling, efficient capital market theory, and pros/cons of government intervention.

This case can be used to achieve multiple learnings objectives (LOs), including:

LO1: Synthesize a complex set of business events into plain English that is easy for a lay person to understand.

LO2: Assess the adequacy of a firm's CSR initiatives.

LO3: Understand how lapses in corporate governance can lead to negative consequences, including risk of bankruptcy.

LO4: Understand the role of the Office of the Superintendent of Financial Institutions in monitoring financial institutions for solvency, liquidity, safety and soundness.

LO5: Understand the role of the Ontario Securities Commission to protect investors and foster efficient and fair markets by making and monitoring compliance with rules governing the securities industry in Ontario.

LO6: Understand the pros and cons of government intervention in stabilizing financial markets.

LO7: Understand the mechanics of short-selling and common strategies short-sellers use to maximize their trading profits.

LO8: Apply agency theory to a case, identifying issues amongst principals/agents and related consequences.

LO9: Assess whether stock price movements support the efficient capital market hypothesis.

Instructors can add additional case requirements to achieve other learning objectives. 


\section{Implementation Guidance}

\section{Classroom uses}

This case has been used in an EMBA introductory accounting/finance course to help bring "to life" the concepts of corporate governance, stock market efficiency, and agency theory. The case provides students with a number of opportunities to grapple with issues they may encounter in their own work places.

Instructors can assign this case as an assignment to undergraduate students as part of a standalone course on accounting theory, finance, or business ethics. Alternatively, students can be asked to read the case prior to class, with the case questions being the basis for an in-depth class discussion. In an MBA or EMBA setting, class discussion is most likely the preferred option. We have found that splitting the class into groups of 4 to 5 students, assigning each group to one question, and asking each group to present their findings/thoughts is a very effective way to balance in-class time restrictions with quality/breadth of coverage.

Instructors can readily adapt the case by adding or removing various questions from the student requirements. Instructors can also determine the depth of analysis required for each question. To facilitate use in a number of courses, the questions have been grouped into four distinct categories; namely, stakeholder analysis, CSR/corporate governance, accounting/finance theory, and finance.

\section{Background materials for Home Capital story}

There has been a plethora of media coverage on Home Capital over the past few years, especially during 2017. Some suggested background readings to supplement the case information include the following:

http://business.financialpost.com/news/inside-the-rise-and-fall-of-home-capital

https://www.theglobeandmail.com/report-on-business/home-capital-group-a-

timeline/article34770189/

http://business.financialpost.com/news/fp-street/osc-accuses-home-capital-of-misleading-disclosureafter-uncovering-fraud-in-mortgage-broker-channel

http://www.newswire.ca/news-releases/home-capital-announces-agreements-to-settle-osc-and-classaction-matters-628505203.html

https://www.bloomberg.com/news/articles/2017-06-28/buffett-in-bag-home-capital-taps-canadapatriots-for-funding

\section{Background materials for CSR theory}

Some videos that may be useful for students include:

https://www.youtube.com/watch?v=EONkGtNU_9w - primer on CSR

https://www.youtube.com/watch?v=B7dDSHwFgKk - CSR at Coca Cola 
https://www.youtube.com/watch?v=CuQ7f-tPOuc - CSR at Cisco

\section{Background materials for finance}

Some videos that may be useful for students include:

https://www.youtube.com/watch?v=Z1LctxzEREE - primer on short-selling

https://www.youtube.com/watch?v=kJzfKuiBK50 - primer on stock market efficiency

\section{Background materials for agency theory}

Some videos that may be useful for students include:

https://www.youtube.com/watch?v=5v7TWKIYoN0\&t=34s - asymmetric information and moral hazard

\section{Suggested Questions and Solutions}

\section{Stakeholder Analysis Questions}

1. Role-play: pretend you are just getting into an elevator with a co-worker. You are in the finance/accounting department; your co-worker is in the marketing department. The discussion briefly turns to the HCG crisis. You have 60 seconds to explain in plain English what happened at HCG and why the stock price has dropped over $70 \%$ as of April 2017.

2. There are a large number of stakeholders in this story i.e. HCG employees, HCG senior management, HCG existing shareholders, HCG new shareholders, HCG deposit holders, HCG mortgage holders, short sellers, the OSC, HCG competitors, OSFI, etc. See below a table listing each of these stakeholders, as well as their respective objectives and observations pre-crisis. Complete the table by identifying how each of the stakeholders was affected by the crisis. In your opinion, if you re-wind the clock two years (just after disclosure of fraud by HCG), what could have been done differently to reach a better outcome?

\begin{tabular}{|c|c|c|c|c|c|}
\hline & HCG employees & $\begin{array}{l}\text { HCG senior } \\
\text { management }\end{array}$ & HCG shareholders & HCG deposit holders & HCG mortgage holders \\
\hline objective & $\begin{array}{l}\text { Earn a fair salary, } \\
\text { with opportunities } \\
\text { for career growth and } \\
\text { collegial work } \\
\text { environment. }\end{array}$ & $\begin{array}{l}\text { Earn a fair salary, with } \\
\text { opportunities to share } \\
\text { in company success } \\
\text { and opportunities for } \\
\text { career growth. }\end{array}$ & $\begin{array}{l}\text { Earn a dividend and capital } \\
\text { appreciation. }\end{array}$ & $\begin{array}{l}\text { Earn a risk-free rate of return in } \\
\text { addition to return of invested } \\
\text { principal. }\end{array}$ & $\begin{array}{l}\text { Obtain financing to purchase } \\
\text { a house. Make payments on } \\
\text { time to improve credit score. }\end{array}$ \\
\hline observation 2014/2015 & $\begin{array}{l}\text { Generally happy; } \\
\text { making large } \\
\text { bonuses. }\end{array}$ & $\begin{array}{l}\text { Excessive focus on } \\
\text { growing the mortgage } \\
\text { business. Minimal } \\
\text { attention to internal } \\
\text { controls. }\end{array}$ & $\begin{array}{l}\text { Steady stock apprecation. } \\
\text { Stock hits } \$ 50.00 \text { per share. }\end{array}$ & $\begin{array}{l}\text { Happy to earn returns slightly higher } \\
\text { than Big } 6 \text { banks. }\end{array}$ & $\begin{array}{l}\text { Mortgage holders obtain } \\
\text { financing on timely basis. } \\
\text { Generally happy with service } \\
\text { provided by HCG. }\end{array}$ \\
\hline observation mid-2017 & & & & & \\
\hline
\end{tabular}




\begin{tabular}{|c|c|c|c|c|}
\hline & HCG short sellers & OSC & HCG competitors & OSFI \\
\hline objective & $\begin{array}{l}\text { Sell shares high; buy } \\
\text { shares low to } \\
\text { maximize trading } \\
\text { profits. }\end{array}$ & $\begin{array}{l}\text { Protect investors from } \\
\text { unfair, improper and } \\
\text { fraudulent } \\
\text { practices. Foster fair } \\
\text { and efficient capital } \\
\text { markets. }\end{array}$ & $\begin{array}{l}\text { Grow their respective } \\
\text { companies, while taking } \\
\text { advantage of market } \\
\text { opportunities as they } \\
\text { arise. }\end{array}$ & $\begin{array}{l}\text { Supervise federally regulated } \\
\text { financial institutions and pension } \\
\text { plans to determine whether they are } \\
\text { in sound financial condition and } \\
\text { meeting regulatory and supervisory } \\
\text { requirements. }\end{array}$ \\
\hline observation 2014/2015 & $\begin{array}{l}\text { Low levels of } \\
\text { shorting activity. }\end{array}$ & $\begin{array}{l}\text { OSC learns of HCG } \\
\text { disclosure issues but } \\
\text { has not yet taken } \\
\text { action. }\end{array}$ & $\begin{array}{l}\text { Alternative lenders are } \\
\text { taking increasing market } \\
\text { share of the mortgage } \\
\text { market, in response to } \\
\text { tighter lending constraints } \\
\text { at Big } 6 \text { banks and } \\
\text { increased immigration. }\end{array}$ & $\begin{array}{l}\text { Financial markets are strong in } \\
\text { Canada. Loan deliquncy rates are near } \\
\text { record lows. Housing market } \\
\text { continues to appreciate as interest } \\
\text { rates are near record lows. }\end{array}$ \\
\hline observation mid-2017 & & & & \\
\hline
\end{tabular}

\section{CSR/Corporate Governance Questions}

1. Discuss how HCG exhibited poor CSR practices. What are the potential benefits for HCG to implement more thorough CSR initiatives?

2. How do CSR initiatives in the banking industry differ from those in other industries, such as mining and manufacturing?

3. Do you believe the corporate governance changes at HCG are adequate to repair the company's credibility?

\section{Accounting/Finance Theory Questions}

1. Many stakeholders blame the regulator - the Ontario Securities Commission (OSC) - for taking too long to address this "fraud" i.e. they knew about it in June 2015, the company came clean about it in public disclosure in July 2015, and yet the OSC did not pursue any action until April 2017. What are your thoughts?

2. Some people think the government should have provided HCG with a backstop as it was facing a liquidity crisis, not a profitability crisis. Others believe the government was right not to step in. (A backstop consists of government intervention to prevent the ruin of an individual private company or the entire financial sector. For example, during the financial crisis of 2007/2008, the US treasury purchased risky and nonperforming debt from many US financial institutions, including mortgages, college loans and auto loans. In addition, the US treasury infused billions of dollars into the banking system to encourage loans between banks and loans to consumers.) 
Given the case facts, what is your opinion? In your answer, consider the backstop which Equitable Bank, Home Capital's closest competitor, received from a consortium of Canada's Big 6 banks (likely in response to urging by the Office of the Superintendent of Financial Institutions (OSFI)).

3. In the aftermath of the OSC story on April 19, 2017, many analysts recommended selling HCG shares. However, there were two major buyers of HCG shares in the aftermath of the OSC release; namely Turtle Creek Asset Management and CIBC. How can different institutions, each with access to the same information, have such very different recommendations/viewpoints as to the investment thesis for HCG?

4. On June 20, 2017, HCG announced that Berkshire Hathaway would be buying a 19.99\% equity share in the company at approximately $\$ 9.55$ per share, an approximate $35 \%$ discount from the company's share price the previous day. The stock price traded significantly higher the next day on announcement of this news, reaching $\$ 20.00$ per share on June $23^{\text {rd }}$. As of August 31, 2017, the stock trades for approximately $\$ 13.00$ per share, still significantly higher than the $\$ 9.55$ noted above. How can the increase in share price be reconciled with efficient capital market theory?

5. On August 21, 2017, HCG issued a press release confirming final court approval of a global settlement regarding a class action lawsuit commenced in February 2017 regarding the company's disclosures in 2014 and 2015. No mention was made as to any class members who excluded themselves from this global settlement. On December 28, 2017, HCG disclosed that approximately 1.7 million common shares eligible for the global settlement opted out of the settlement. HCG further disclosed that of these 1.7 million shares, 390,900 shares are owned by Roland Keiper and Brian Chapman and 1,234,700 shares are owned by West Face Long Term Opportunities Global Master LP. The total amount claimed as damages amounts to $\$ 72$ million. Speculate as to why it took HCG four months to disclose the fact that that 1.7 million shares opted out of the settlement. In your opinion, does this omission in the August 21st press release represent a material misleading statement?

\section{Finance Related Questions}

1. Compile a timeline of events in the HCG story since April 19, 2017 (consider using sedar.com to search for HCG news releases for the period April 19, 2017 to August 31, 2017). Next, chart the significant fluctuations in HCG share price during this same period (consider using Google Finance to obtain this chart). Do all the news releases correspond to a significant change in share price? Do all the significant share price 
changes correspond with a news event? Based on your observations, do you think the market is efficient? Why/why not?

2. At its peak, approximately $60 \%$ of HCG's shares were shorted, a very high number by any comparison. How does a $60 \%$ short position compare with other publicly traded companies? How can so many shares be shorted? Can shareholders who are "long" a stock prevent their broker from "lending" their shares to short-sellers? The short position in HCG decreased significantly from April to July 2017. Why?

3. Marc Cohodes, an outspoken short-seller from the U.S., is considered to have played a pivotal role in the fear-mongering that brought HCG "to its knees". In a nutshell, Cohodes used the OSC lawsuit coupled with Kathleen Wynne's decision to implement a foreign buyer tax in Ontario to cool the housing market as support for his assertion that HCG shares are worthless. Some see Cohodes as a villain, others as a hero. What is your opinion? If a villain, what corrective action should be taken against Cohodes or others like him in the future?

4. Why do you think HCG's board of directors accepted Buffett's offer and not others, which included out-right sale of the company, piece-meal sale of various assets, etc.? Why do you think none of Canada's big banks made an offer for HCG? For information on other offers received and management rationale for supporting the Buffett deal, please refer to Home Capital's September 12, 2017 management information circular, available on sedar.com. 
${ }^{\mathrm{i}}$ Marc Cohodes is a retired U.S. hedge fund manager

ii http://www.bnn.ca/video/home-capital-stock-still-risky-baskin-wealth 1152385

iii Barry Schwartz is chief investment officer at Baskin Wealth Management

${ }^{\text {iv }}$ http://www.baskinwealth.com/baskin-wealth-management-letter-to-clients-concerning-home-capital-group/

${ }^{\mathrm{v}}$ http://www.homecapital.com/profile.asp

${ }^{v i}$ http://quote.morningstar.ca/Quicktakes/Insiders/

vii http://people.equilar.com/bio/

viii

http://www.homecapital.com/corpgov\%20documents/Code\%20of\%20Business\%20Conduct\%20and\%20Ethics\%20

Policy.pdf

${ }^{i x}$ https://www.fin.gc.ca/n11/11-003-eng.asp

${ }^{\mathrm{x}}$ http://www.fin.gc.ca/n10/10-011-eng.asp

${ }^{x i}$ https://www.canada.ca/en/financial-consumer-agency/services/mortgages/down-payment.html?wbdisable=true

xii https://www.theglobeandmail.com/report-on-business/home-capital-group-a-timeline/article34770189/

xiiihttp://business.financialpost.com/news/fp-street/osc-accuses-home-capital-of-misleading-disclosure-afteruncovering-fraud-in-mortgage-broker-channel/wcm/65ae8897-98c5-4ef2-a9a9-f6abcdf6a033

xiv http://www.newswire.ca/news-releases/home-capital-group-announces-departure-of-ceo-martin-k-reidappointment-of-interim-ceo-and-commencement-of-search-for-permanent-replacement-617228533.html ${ }^{x v}$ http://www.homecapital.com/presentations/investor2017/Q1\%202017\%20Investor\%20Presentation.pdf

${ }^{\text {xvi }}$ http://www.newswire.ca/news-releases/home-capital-announces-agreements-to-settle-osc-and-class-actionmatters-628505203.html

xvii https://www.bloomberg.com/news/articles/2017-06-28/buffett-in-bag-home-capital-taps-canada-patriots-forfunding

xviii http://business.financialpost.com/news/fp-street/in-home-capitals-mortgage-mess-blametheunlucky-brokers 